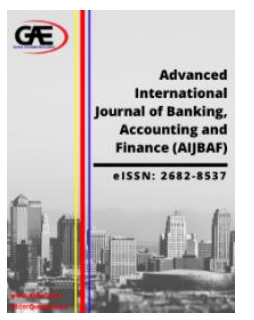

\author{
ADVANCED INTERNATIONAL JOURNAL OF \\ BANKING, ACCOUNTING AND FINANCE \\ (AIJBAF) \\ www.aijbaf.com
}

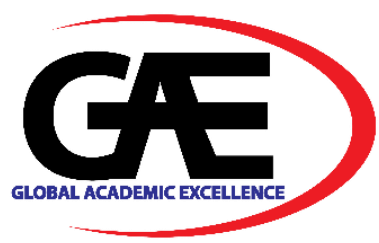

\title{
IMPACT OF CHINA'S INVESTMENT ON AFRICA TRADE AND FINANCING: CASE OF DJIBOUTI
}

\author{
Kadra Ismail Mohamed ${ }^{1}$
}

1 Lecturer at Department of Economic and Management Science at Djibouti University \& PhD Candidate at International Islamic University Malaysia

Email: makadra88@gmail.com

\section{Article Info:}

Article history:

Received date: 25.11 .2021

Revised date: 15.12 .2021

Accepted date: 27.12 .2021

Published date: 31.12 .2021

\section{To cite this document:}

Mohamed, I., K. (2021). Impact of China's Investment on Africa Trade and Financing: Case Of Djibouti. Advanced International Journal of Banking, Accounting, and Finance, 3 (9), 75-85.

DOI: $10.35631 /$ AIJBAF.39006.

This work is licensed under $\underline{\text { C B B 4.0 }}$

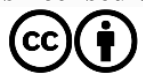

\begin{abstract}
:
China economic reform led to increase substantial bilateral commercial relation between china, and rest of the world particularly African countries. African soil is rich with natural resources, which is yet to exploit. Moreover, some horn African countries exhibit vibrant and strategic port that link the trade between Africa, Europe and Asia countries. As result, china has become sources of funding, strong trade partner and major investor for those countries. For the past eleven years china has succeed to seize the Djibouti ports, hence china win strategical points. This is because Djibouti lies at the intersection of shipping lanes vital to many economics in both Europe and Asia; and it is the gateway of landlocked country in horn of Africa (Ethiopia). Therefore, china has widely invest in Djibouti in term of providing funding for construction, bilateral trade mostly maritime financing. This study is intend to analyse the long-term effect of china's investment on trade and financing in Djibouti. To analyses the case, this study used trade and debt data of Djibouti from 1992 to 2019. The finding confirmed that china investment positively affect the trade activities as well as transportation logistic, but it adversely affect the financial state of Djibouti.
\end{abstract}

Keywords:

China, Debt, Financing, Investment, Trade

\section{Introduction}

China's FDI and bilateral trade in Africa is tremendously increasing compare to USA and rest of western countries. Recent data has shown hug gap between china-Africa FDI data and USAAfrica. As it indicate in Figure1 from year 2009 to 2019 china FDI reached 6 billion USD whereas the USA and Africa FDI decline sharply below zero value. The same case holds for 
Volume 3 Issue 9 (December 2021) PP. 75-85 DOI 10.35631/AIJBAF.39006

trade and other economic cooperation. The cause of uplifting Chinese investment in Africa is due to china non -intervene policy to the African government policy and practice as well as the need of African countries to develop their infrastructure sector to boost their economic growth, these reasons have become and impetus for strong economic cooperation between China and Africa. Furthermore, China's Belt and Road Initiative (BRI) project has come to be the source of funding for many east African countries such as Kenya, Tanzania, Uganda, Somalia and Djibouti. BRI intuitive is to improve trade connection between china and its trade partners in Africa, Asia and Europe. Recently Djibouti has turn out to be the centrepiece of Chinese BRI intuitive the reason being that Djibouti is key of global shipping lanes make it an attractive location for the country with global maritime investment. ${ }^{1}$ For the past eleven years china has succeed to seize the Djibouti ports such as the Doraleh container terminal, Doraleh multi prospect, rail way and road projects linking the country with Ethiopia. Hence, China engagement in Djibouti increases at increasing rate. However, is China involvement in Djibouti serving the interest of local commerce? , is it saddling Djibouti with debt? Alternatively, is it hindering the financing capability of Djibouti? This study intends to answer above questions by analysing the long-term implication of china's maritime investment on traders and financing in Djibouti.

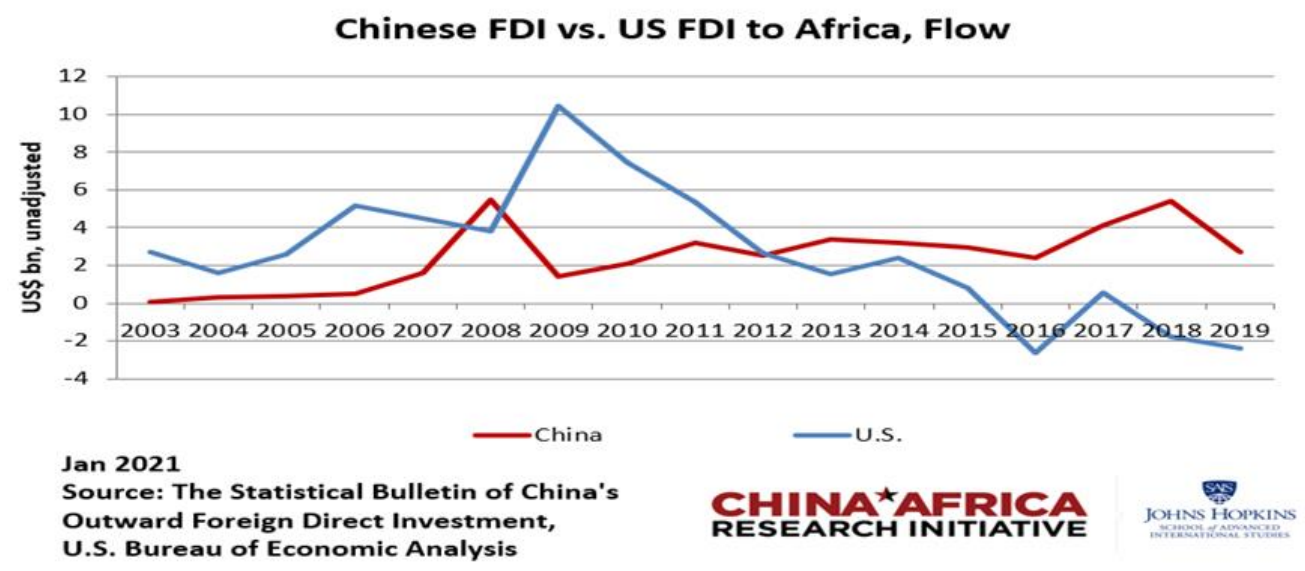

\section{Figure1: Chinese FDI VS US FDI To AFRICA}

\section{Objectives of the Study}

1. To analyse long-term effect of china's investment in Djibouti trade and finance

2. To examine china's mode of financing in Djibouti

\section{Research Questions}

1. Does china investment Affect trade and finance in Djibouti?

2. Does china's mode of financing affect Djibouti's debt level?

\section{Literature Review}

Before digging into recent development in China investment in east Africa, it is important to visit the early China involvement in east Africa and link it to the current statue of China-East Africa investment, as well as reviewing the other authors view on East Africa maritime investment. In this section, also I will develop conceptual framework of the study.

\footnotetext{
${ }^{1}$ www.crs.gov 2019

Copyright $\odot$ GLOBAL ACADEMIC EXCELLENCE (M) SDN BHD - All rights reserved
} 


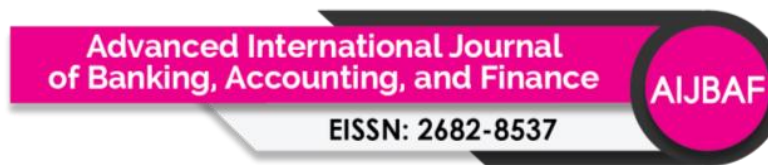

Volume 3 Issue 9 (December 2021) PP. 75-85 DOI 10.35631/AIJBAF.39006

Historically China and Africa had tied up with bilateral relation before the independence of those countries. As noted by Abdillahi (2020) Initially, China's engagement in Africa has been trace back to Ming Dynasty (1368-1644). Nevertheless, the cooperation during time was mainly to support the African countries for liberation and aid programmers in the 1960s and 1970s. Such as, the Tanzania Zambia Railway, constructed in the 1970s, is a significant symbol of China's active role in supporting African governments towards their liberation movements. (Anna Katharina, 2016). However, this cooperation had slowdown in 1980 until the issue of Tiananmen Square crackdown then PRC realized the political significance to engage in Africa, thus china enrich the political and economic cooperation with African countries.

Contemporary ties with Africa is back to the recent china economic development. For china to maintain its status as the world's factory and the second largest global economy, china demand natural resources to meet its production capacity and to compete in global market with other developed countries. Hence, china have started to build strong economic cooperation with its historical partner (Africa) and that was a blueprint of current Africa and china partnership. As result, majority of African countries (49 out of 54) have excellent bilateral relations with China (known as the People's Republic of China. (Sandy Edward, Yao Jun \& Qian Yiguan 2013). Henceforward, China has organized four forums on China-Africa cooperation that puts stress on trade and economic cooperation. The first in 2000, focused on globalization and enhancement of China-Africa economic cooperation. A second summit held in Ethiopia, focus on the deploying the blueprint with special emphasis on human resource development, investment and trade corporations. A third summit "the FOCAC Summit" held in Beijing 2006, initiate the new implementation of Education aid for Africa. (Sandy Edward, Yao Jun \& Qian Yiguan 2013). Like other African countries regions China-east African relation is not limited on exportation and importation, rather is set of relation that include infrastructure financing, maritime financing as well as FDI. From (FOCAC) to Belt Road intuitive, BRI establish on 2013 and it mission was to increase the economic integration and connectivity (such as infrastructure, trade, and investment) with its neighbours and various trading partners in Asia, Africa, Europe ${ }^{2}$. It encompasses with a maritime financing, infrastructure, network cable and Silk Road. East African countries are core of Belt Road intuitive as it stated by Candice Newcomb (2020) china investment in Kenya emphasize on developing the Mombasa port by building railway that link between Mombasa ports with landlocked neighbouring country.

Likewise, Ethiopia is also the flagship of Chinese BRI project, which intend to advance the connection by lands and sea between China and its trade partners in Asia, Africa, the Middle East, and Europe through infrastructure plans. In addition, Djibouti ports are also fall under BRI intuitive project ${ }^{3}$. Recent interest of china in horn of Africa, particularly Djibouti has raised a concern among the research to analyses the effect of such engagement on Djibouti agency power, economic growth, labour force as well sovereignty issue. Projected conducted by Jean Pierre Cabestan( 2020) has concluded that, the Djibouti's government strategy to maintain multiplier partnership with other countries such as France and U.S.A, plus its strategical location of Djibouti has gave the country the ability to exert some agency in its relations with external partners, including China.

\footnotetext{
${ }^{2}$ China's Economic Rise: History, Trends, Challenges, Implications for the United States, Congressional Research Service
} 
Volume 3 Issue 9 (December 2021) PP. 75-85 DOI 10.35631/AIJBAF.39006

Moreover, study conclude by Peter, Isaac\& Corner(2020) has ascertained that China involvement in Djibouti maritime investment had enhance the Djibouti's ports as well as commercial transport and logistic hub, however, has not lived up to the hype yet (Peter, Isaac\& Corner2020). This is because political uprising in Ethiopia as well as increasing burden of debt had hampered the positive spillover of Chin's maritime investment in Djibouti. Furthermore, study done Zach Vertin ( 2020) in which author analyses rivalry act between china and USA over red Sea, has confirmed that china succeeds to have great rivalry power in Red sea through its great investment in Djibouti. Zach Vertin mentioned also that despite the flurry of Chinese investment and high growth rates, the rising tide has yet to lift all boats. Most ordinary Djiboutian do not feel the impact of these gains. In addition, as far as labor force concerns China has failed to provide adequate remuneration, working condition as well absence of transferring managerial skills to Africa labor including Djibouti. (Nancy, Muthoni, Alfred, Wang and Salun, 2019).

\section{Conceptual Development}

\section{International Trade}

"Trade has existed since ancient times, and historical development of nation is the result of ensuring its needs, both physical and moral, as well as intellectual. Because no country has available all the material and human resources need." (Elena Ramona, 2016, P, 244). Similarly Danjuma, Habakkuk, Ames define "International trade refers to as the transferee of goods and services which include capital from one country to another" $(2014, \mathrm{p} 2)$. Therefore, Trade is simply exchange good and services between the buyers and sellers with price paid by buyers. Likewise, international trade is export, import activities between the countries. International trade operation should be abide with WTO rules and regulation. Doctrine of international trade is endowment of resources whether it is capital, labor, and technology. Hence, international trade play an essential role to promote the economic growth of countries. As stated by Danjuma, Habakkuk, Amos( 2014) international trade has positive impact on emergent market economy, because of providing additional capital, fostering multilateral, bilateral and regional trade agreements among member countries, raising the overall income, marketing resources endowment and enable the developing countries to borrow funds at very low interest rates. The similar fact holds for underdeveloped countries.

For example, Uganda faces a population boom and are under-industrialized, this trend creates a significant opportunity to create employment by attracting labour-intensive manufacturing shifting from China. Therefore, labour-intensive manufacturing shifting from China to Uganda. (David Dollar, Akura Mugyenyi, and Nicole Ntungire, 201).With an improvement in investment climate, Uganda also stands to expand its involvement in global trade, including Global Value Chains (GVCs) (Tom Ogwang \& and Frank Vanclay, 2021).Bearing in mind the benefit of international trade the underlying issue is how to improve the process of international trade? The trade can become more beneficial through maritime financing and trade financing. Finance is the providing funding need to a given project or investment opportunity. Normally the financial institutions and financial markets are the source of fund for most business activities. There are mainly two mode of financing equity and debt base financing. Both of them has its unique risk, cost and return. Sometimes there is an opportunity for the investors to use mixed structure, which they can combine the debt and equity financing. Thus, financing is a gateway to enrich business sector of the country, so we have trade financing, project financing, maritime financing and so on so forth. 


\section{Maritime Financing}

The efficient trade depend on well infrastructure port that equipped with modern equipment. Thus, many international ports seek private investors to finance the port in order to improve the performance of ports and terminals. As it, confirmed by Holman Fenwick (2013) that many ports have comprehended that they need to decrease congestion and minimize delays if they are to generate profit from rising imports and exports activities. In that case, private capital as well as foreign investors financing has proved crucial to increase the ports and terminals efficiency. There are different types of port financing such as concession, divestiture, Greenfield project and management and lease contract. One of dominate project to rebuild and enhance ports and terminal of east African countries is belt and road initiative. The main drivers of BRI are security, market, and energy (Nancy, Muthoni, Alfred, Wang and Salun, 2019).

Insofar, BRI has enhance domestic integration and regional connectivity. Due the fact that Africa consist of large number of small landlocked countries with no access to port, also poor infrastructure and higher transportation cost have hinder African countries to actively participate in global value chain. Consequently, investment in highway and railway project is crucial to alleviation of blockage (Nancy, Muthoni, Alfred, Wang and Salum, 2019). Djibouti is a centre point of BRI, because it plays a critical role in Ethiopia's exports and imports as the major route and a strategic commercial hub for imports and exports to and from Europe, Asia, and the rest of Africa. Therefore, the railway has alleviated the region's bottleneck leading to wider export market access to manufactured goods from Ethiopia. In addition, Djibouti expects the greater connectivity between the red sea and Atlantic Ocean through a rail network. (Nancy, Muthoni, Alfred, Wang and Salum, 2019). As result Maritime, investment will enhance international trade and facilitate easy flow of import and export, and that in turn will boost GDP of the country.

Nonetheless, mode of investment will have positive or negative spill over on financial development it depends on financial structure of the country. As it proved by Abdul, Ping, Mahmood, Muhamad and Judith (2021) FDI shows negative effect on Africa while it has positive impact of Asian and developed country, and this contrary effect caused by weak financial structure of most African countries. Moreover, Tom and Frank (2021) noted that African development countries has benefited from China investment, but in long- run increasing national debt might cause social unrest and it will limit the return of investment.

So African countries should develop proper tool and logistic to generate benefit from china FDI, whether it is infrastructure, trade and maritime financing. China invest in Djibouti heavily to extend that china debt in Djibouti is about $70 \%$ of GDP. China and Chinese state-owned firms had invested nearly $\$ 10$ billion in Djibouti (Aadil Brar, 2021). Therefore, Djibouti has accumulate large debt to transform the country to free trade and logistic hub in east African country. However, that strategy had create a debt distress, as it ascertain by IMF that Djibouti willingness to promote the country to logistic hub in East Africa. Has result in debt distress, which lead to huge risk. Debt base financing is estimate to deteriorate financial development of the country. 


\section{Conceptual Framework of Study}

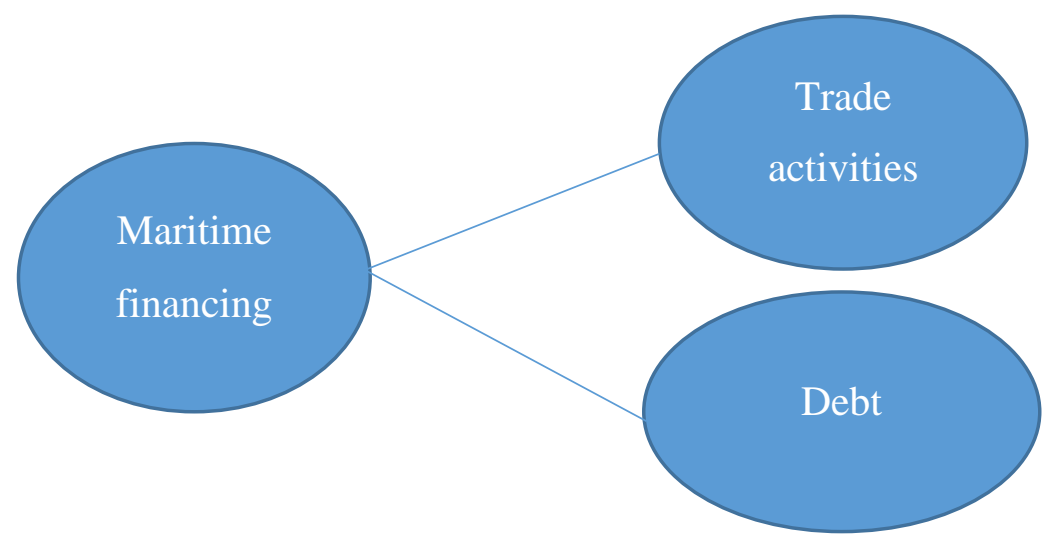

\section{Methodology}

The research is descriptive in nature, because I am going to investigate whether China maritime investment has an impact on Djibouti trade activities and to what extend China financing model affect Djibouti debt level. To serve that purpose, I will use the trade data from (1992 -2019) to assess trend of export and import between China - Djibouti as well as between Djibouti and other countries such as (Ethiopia, Somalia, USA and France). This is because advancement of the ports and terminal will enhance the import and export activities of any given country. Djibouti is trade base economy it does not have a well structure manufacture or agricultural sector. It drives its economic growth from trade activities such as shipping liner connectivity, export of transport and travel services. Therefore, this research will observe the change of trade activities before China involvement in Djibouti ports and after China's involvement in the ports and terminals of Djibouti. By doing so we can ascertain the effect of China engagement in maritime of Djibouti. I will also explore Djibouti debt information from 2013 to 2019, these years China heavily invest in Djibouti ports, and nature of investment was debt base financing. Therefore, I will use total reserve as percentage of total external debt ratio from 2013 to 2019 as well as total external debt of Djibouti as percentage of GDP in same period. These ratios are very significant to examine the country capability to meet its debt obligation., Thus this study use these ratios to determine whether Djibouti government was able to pay back the debt or it has a huge debt obligation to meet, which can put the country into debt distress. The secondary data will be trace from statistical bulletin of chain's outward of direct investment and US. Bureau of economic analysis as well as World Bank and Djibouti central bank data. Using excel sheet I will analyze trade data between Djibouti and its trade partners as well as Djibouti debt level. Base on the finding I will determine the effect of China engagement in Djibouti on trade and financing stand of the country.

\section{Data Analysis}

\section{Trade}

China's growing engagement in Djibouti consists of commercial and military undertaking, in order to establish a strategic position for China in the western Indian Ocean and the Horn of Africa. China exporting to Djibouti has drastically increase, especially from 2009 and onward 
Volume 3 Issue 9 (December 2021) PP. 75-85 DOI 10.35631/AIJBAF.39006

to reach beyond 2000 million Dollars in 2019 as it indicated in Figure 2. On the other hand, the importation from Djibouti to china remain below 1 million dollars as it shows in Figure 3. As it clear from above graphs china is among major exporter to Djibouti however, china is not major importer of Djibouti. Consequently, as far as bilateral trade between china and Djibouti concern it exhibited huge trade balance deficit as it indicated in Figure4. In 2019 the trade deficit was 2190 million dollars.

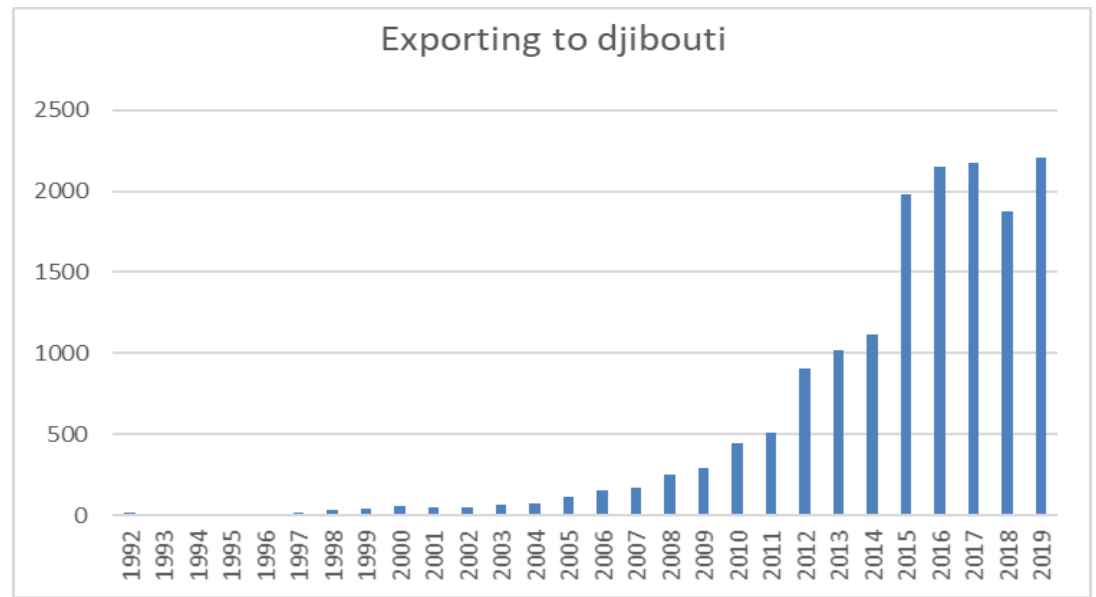

Figure 2: Annual Chinese export to Djibouti in US\$ mn

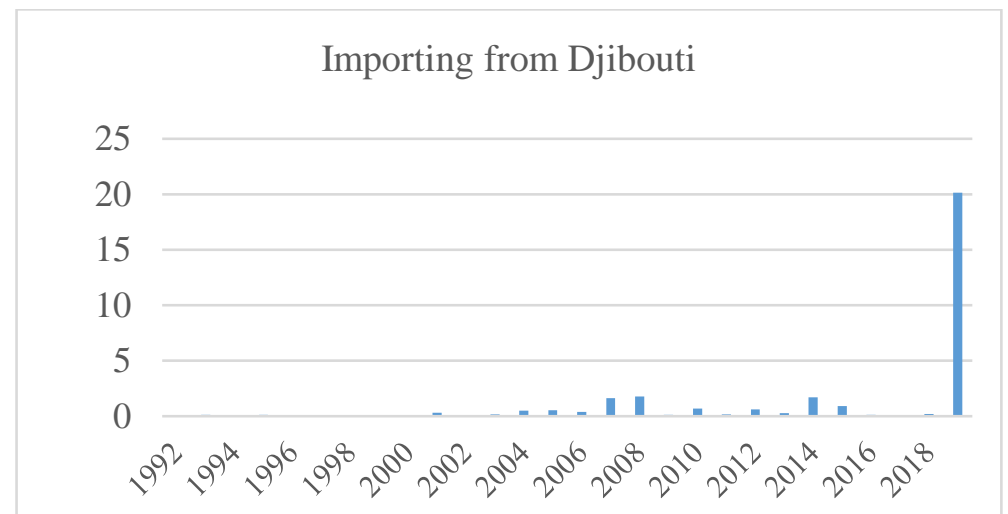

Figure 3 Annual Chinese importing from Djibouti in US\$ mn

Major importers of Djibouti are Somalia, Ethiopia, Sudan and Egypt. Ethiopia is landlocked country and rely on Djibouti ports, as result the demand for logistic services increase as Ethiopia is witnessing economic growth. Thus, the export and import from and to Ethiopia will increase as well, and that will have a positive spillover on Djibouti trade activities. Therefore, the total exports of Djibouti is increasing in continuous manner, and that lead to a decline of Djibouti trade balance deficit. As it noted in trading economy ${ }^{4}$ exports in Djibouti increased to 710204 DJF Million in 2019 from 625926 DJF Million in 2018. Therefore, we can conclude that the modernizing Djibouti ports has boosted the trade activities, which in turn has a positive impact on Djibouti economic growth.

\footnotetext{
${ }^{4}$ https://tradingeconomics.com/djibouti/exports

Copyright $\odot$ GLOBAL ACADEMIC EXCELLENCE (M) SDN BHD - All rights reserved
} 


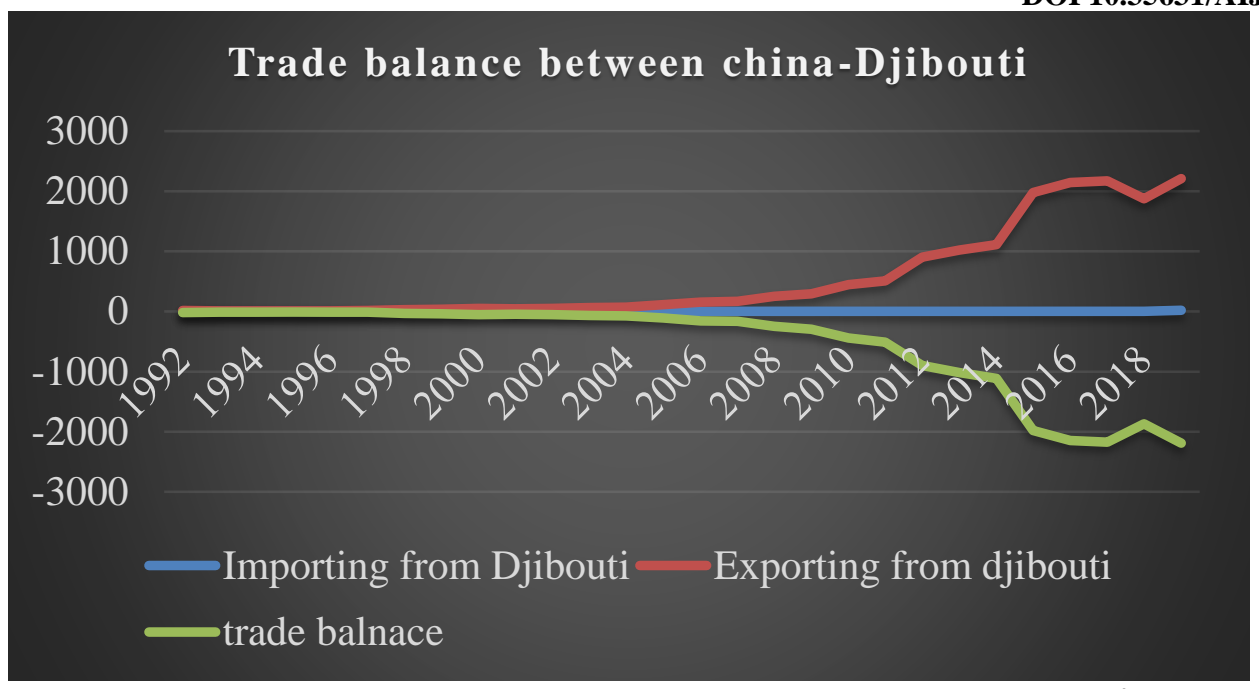

Figure 4: Trade balance between China and Djibouti in US\$ mn

\section{Financing Projects and External Debt}

China finances a several project in Djibouti such as railway between Djibouti and Ethiopia, pipe lines water, modernizing Djibouti ports, and establishing the free trade Zoon. Different projects required hug fund to realize it, as result Djibouti rely on China to provide funding need to accomplish those project. China was not only injecting funds to the projects but Chinese construction companies as well as Chinese banks are also involving in projects. The mode of financing of all the above projects are debt base financing and all of it took place under the umbrella of BRI project. Henceforth, Chinese loan to Djibouti government has increase particularly form year to 2013 to 2017 and it is start to decline starting from 2018. To assess the possibility of Djibouti government to meet the debt obligation I have used total reserve as percentage of total external debt ratio from 2013 to 2019. The data showed in Figure: 6 that the total reserve of Djibouti has fallen below the amount of external debt by $19.5 \%$ by 2020 . Consequently, Djibouti government is saddle with a debt, and this has negative impact of financing opportunity of a country as well as overall economic performance of the country.

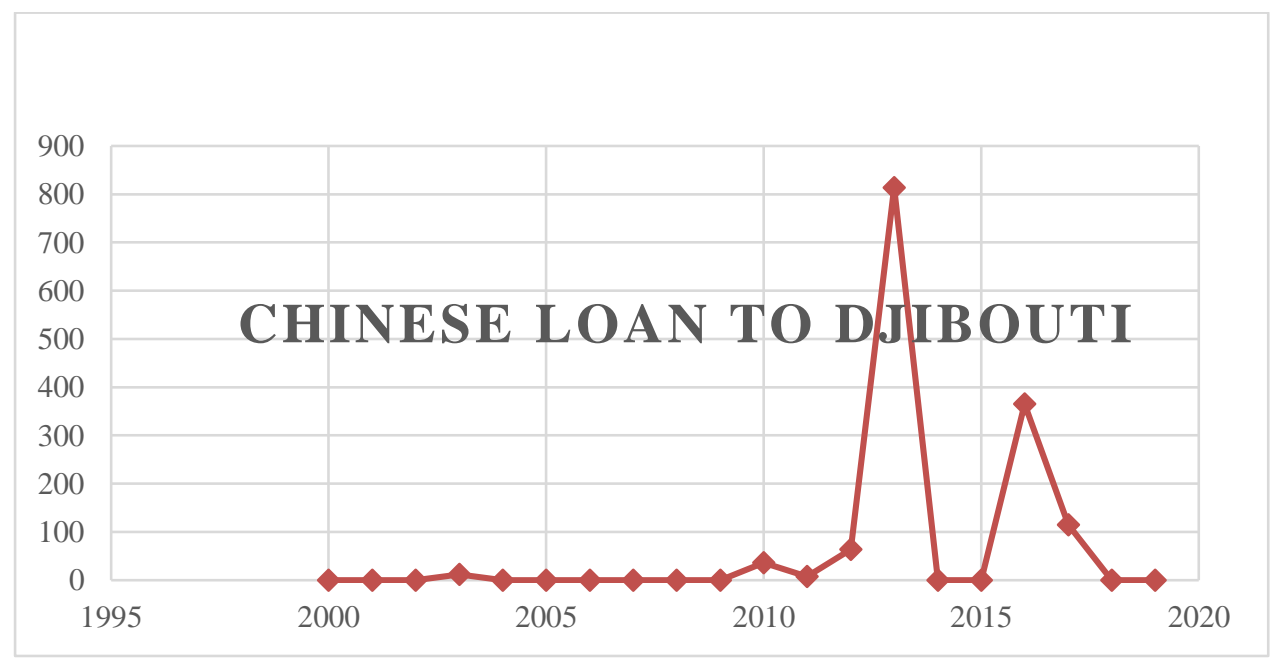

Figure 5: Annual Chinese Loans to Djibouti in US\$ mn 


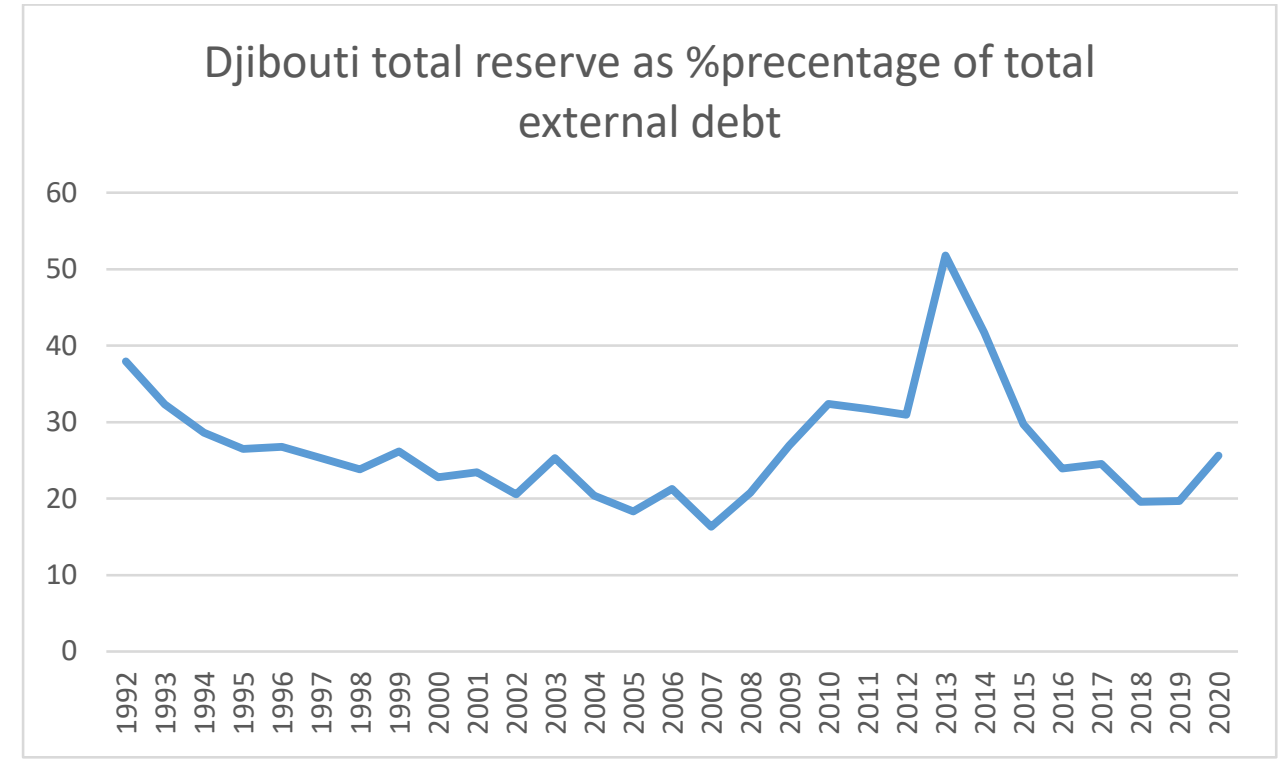

Figure 6 : Djibouti Total Reserve Ration as\% of Total External Debt

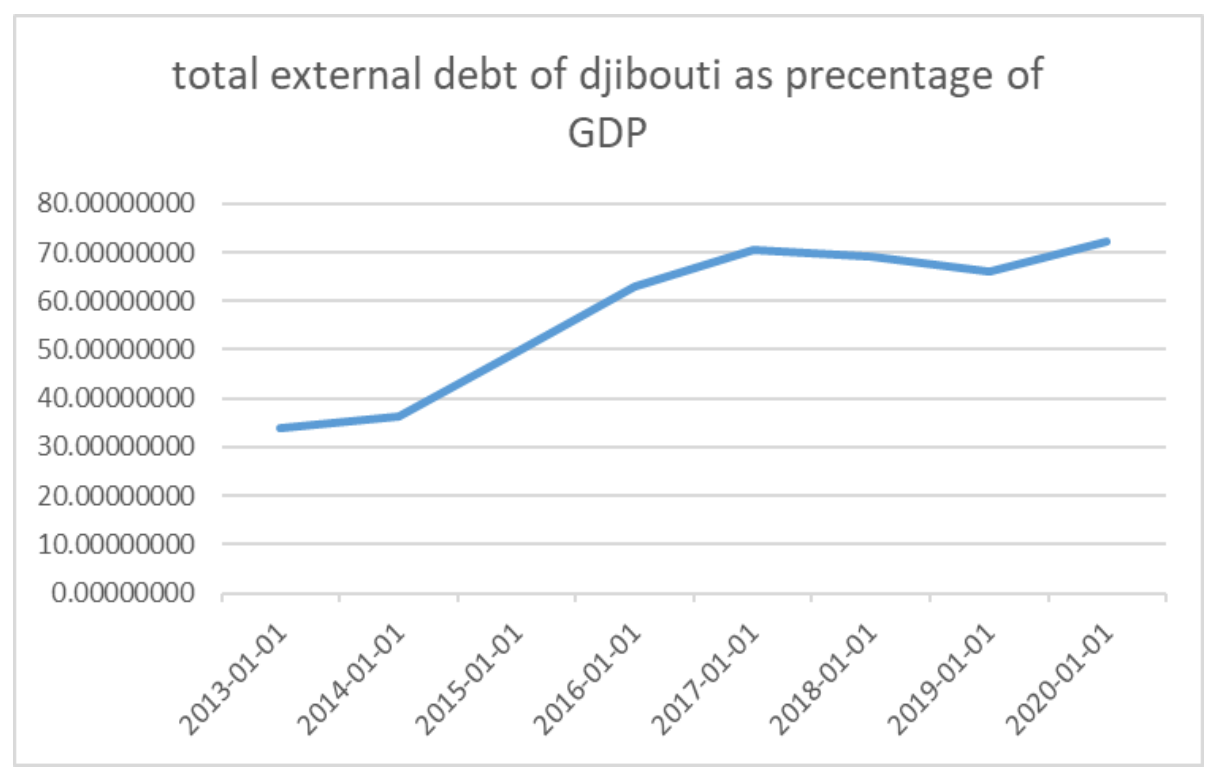

Figure 7: Total External Debt of Djibouti as Percentage of GDP

\section{Discussion}

\section{Impact of China Maritim Investment on Trade}

Djibouti strength lies on it stratgical location that shape it is economic, trade is growing rapidly as data shown to boost the economic growth. In addition Ethopia current econonmic growth has positive impact on djibouti as export and import of ethopia increase, thus the profit that djibouti generate from logistice services will go up as well. Hence the finding of the study is line with the pervious finding which asertaint that maritime investment will generate huge profit from rising imports and exports activities. Chinese investment on ports of djibouti has Copyright $\odot$ GLOBAL ACADEMIC EXCELLENCE (M) SDN BHD - All rights reserved 
Volume 3 Issue 9 (December 2021) PP. 75-85 DOI 10.35631/AIJBAF.39006

increase trade activity and improve djibouti's connetivity line as date from year of 2013 and 2018 indicated. Furthermore, the covid 19 does not severely effect the trade of djibouti as it has been showed in trade data of djibouti. Henceforth, improvement of Djibouti's trade activities is inline with finding of other reseraches, who ascertained that maritime investment enhances trade activities domestically as well as global level.

\section{Effect of China's Mode of Financing on Djibouti's Debt Level}

China provide a fund to djibouti through debt base financing. Dominate strategy deployed by djibouti government is resource financed infrastructure. Hence, china provide funding need to Djibouti government in return to receive the profit generated from project for specific period or to own shares of the particular project. Furthermore, construction companies are Chinese companies also Chinese private banks such as china Exim bank involve in financing the trade activities. Therefore, china is feeding Djibouti external debt to point that Djibouti become highly indebted to china government and this negatively affect financing capacity of the country, because paying back that debt will leave no room for Djibouti to expand its economy.

\section{Conclusion \& Recommendation}

In short, China engagement in Africa has increase gradually to serve the need for natural resources as well as finding demand for their manufacturer product. It also helps African countries to meet their infrastructure needs and that in turn will boost GDP of the country. Furthermore, china investments are concentrated in infrastructure sector and maritime financing, which enhance international trade and facilitate easy flow of import and export. However, the mode financing whether it is resource-financed infrastructure or a resources-forinfrastructure will have an impact on financial stand of country. The finding of this paper revealed that China maritime investment has positively contributed to advancement of trade activities. Given the fact that Djibouti is gateway of most landlocked country in east Africa. Thus, maritime financing transferred Djibouti ports to more efficient and facilitate world trade flow between east Africa, china and rest of the world. Exports in Djibouti increased to 710204 DJF Million in 2019 from 625926 DJF Million in 2018. However, the mode financing used by china to provide a fund to the Djibouti government as well as financial structure of Djibouti has adversely affect Djibouti financing capability. To the extent that $79 \%$ of its GNP is, consist of an external debt. Hence, FMI confirm that Djibouti has fall under the debt trap. Henceforth, the study has conclude that China FDI has positive long-term impact on trade flows, but it is saddling Djibouti with debt. For Djibouti to regain its economic potential, I will recommend the following: 1) Djibouti government should wisely take advantage from its strategical location by inviting other investors to invest in Djibouti. 2) The government should develop strategical plan to manage the debt. 3) Djibouti SMEs should be given incentive to involve in maritime business. Also local construction company must have a dominant role in construction projects that taking place in Djibouti. However, this study has some limitation: first, this article use excel sheet to analyse the relationship between maritime investment, trade activities and debt did not use econometric model to assess the relation, secondly, did assess how china investment affects the labour. 


\section{References}

Abdilahi, A. I. (2020). Cooperation and development between China and East Africa. Open Journal of Social Sciences, 08(04), 153-166.

Bjelić, P. (2008). Foundation of New concept of International Trade. Conference: ICES 2008 Conference in Sarajevo Volume: Transitional Challenges of EU Integration and Globalization

Crescenzi, R. Limodio, N. Roentgen,V. (2021). China impact of Chinese FDI in Africa: Evidence from Ethiopia, London school of economic and political Science Institute of global Affair.

Dollar, D., Mugyenyi, A., and Ntungire, N.( 2017). How can Uganda benefit from China's Economic Rise? Policy note. International growth center

Dutton, Peter A., Kardon, Isaac, B. and Kennedy, Conor M., "China Maritime Report No. 6: Djibouti: China's First Overseas Strategic Strongpoint" (2020). CMSI China Maritime Reports. 6.

Githaiga, N. M. Burimaso, A. Bing, W. \& Ahmed, S. M. (2019) The Belt and Road Initiative Opportunities and Risks for Africa's Connectivity. World Century Publishing Corporation and Shanghai Institutes for International Studies China Quarterly of International Strategic Studies, Vol. 5, No. 1, 117-14

Hassan, D. N. Aboki , H . Audu , A.A. (2014) International Trade : A mechanism for Emerging Market economies. International Journal of Development and Emerging Economies Vol. 2, No.4, pp. 24-32,

Hinga, S. E., Jun, Y., Yiguan, Q. ( 2013). China-Africa Cooperation-An outstanding relationship Built on Mutual Respect and Common Benefits: A Review, International Research Journal of Social Sciences ISSN 2319-3565 Vol. 2(9), 26-32,

Majeed, A., Jiang, P., Ahmad, M., Khan, M. A., \& Olah, J. (2021). The Impact of Foreign Direct Investment on Financial Development: New Evidence from Panel Cointegration and Causality Analysis. Journal of Competitiveness, 13(1), 95-112.

Newcomb, Candice, S. (2020). "The Impact of Chinese Investments on the Kenyan Economy." Master's thesis, Chapman University,.https://doi.org/ 10.36837/chapman.000190

Ogwang, T., Vanclay, F. (2021). Resource-Financed Infrastructure: Thoughts on Four Chinese-Financed Projects in Uganda. Sustainability 2021, 13, 3259. https://doi.org/ $10.3390 /$ su 13063259

Sen, Sunanda (2010). International trade theory and policy: A review of the literature, Working Paper, No. 635, Levy Economics Institute of Bard College, Annandale-on Hudson, N

Sthal, A.K. (2016). China's relation With Sub- Saharan Africa. Institute Affair International

Tereza, E. R. (2016). The concept of international trade and main classical Theories. Practical application of science volume VI, issue 2(11)

Willan, F. H. ( 2013). Global Investment in ports \&terminals, Holman Fenwick Willan LLP Friary Court, 65 Crutched Friars, London EC3N 2AE. United Kingdom. 